\section{A FRAGMENT OF PRIMEVAL EUROPE}

WIIEN the history of the growth of the European area is traced backward through successive geological periods, it brings before us a remarkable persistence of land towards the north. The stratificd formations bear a generally concurrent testimony to the existence of a northern source whence much of their sediment was derived, even from very early geological times. In their piles of consolidated gravel, sand, and mud, their unconformabilities and their buried coastlines, they tell of some boreal land which, continually suffering denudation, but doubtless at intervals restored and augmented by upheaval, has gradually extended over the whole of the present European area. The chronicles of this most interesting history are at best imperfect, and have hitherto been only partially deciphered. They naturally assume an increasingly fragmentary and obscure character in proportion to their antiquity. Nevertheless traces can still be detected of the shores against which the oldest known sedimentary accumulations were piled. The shores have of course been deeply buried under the deposits of subscquent ages. But the whirligig of time bas once more brought them up to the light of day by stripping off the thick piles of rock beneath which they have lain preserved during so vast a cycle of geological revolutions. I shall here describe a fragment of this earliest land, and allude to some of the geological problems which it suggests.

In the north-west of Scotland, along the seaboard of the counties of Ross and Sutherland, a peculiar type of scenery presents itself, which rcappears nowhere else on the mainland. Whether the traveller approaches the region from the sea or from the land, he can hardly fail to be struck by this peculiarity, even though he may have no specially geological eye for the discrimination of rockstructures. Seen from the westward or Atlantic side, as, for example, when sailing into Loch Torridon, or passing the mouths of the western fjords of Sutherlandshire, the land rises out of the water in a succession of barc rounded domes of rock, crowding one behind and above another, as far as the eyc can reacb. Not a trec or bush casts a shadow over these folds of barren rock, It might at first be supposed that even heather had been unable to find a foothold on them. Grey, rugged, and verdureless, they look as if they had but recently been thrust up from beneath the waves, and as if the kindly hand of nature had not yet had time to clothe them with her livery of grcen. Strange however as this scenery appears when viewed from a distance, it becomes even stranger when we enter into it, and more cspccially when we climb one of its more prominent heights and look down upon many square miles of its extent. The whole landscape is one of smoothed and rounded bosses and ridges of bare rock, which, uniting and then separating, inclose innumerable little tarns (Fig. 1). There are no definite lines of hill and valley; the country consists, in fact, of a seemingly incxtricable labyrinth of hills and valleys, which, on the whole, do not rise much above, nor sink much below, a general average level. Over this ex panse, with all its bareness and sterility, there is a singular absence of peaks or crags of any kind. The domes and ridges present everywhere a rounded, flowing outline, though here and there their outline has bcen partially defaced by the action of the weather.

The rocks that have assumed this extcrnal contour are the Fundamental, Icwisian, or I.aurcntian gnciss, which, as Murchison first showed, form the platform whereon the rest of the stratificd rocks of Britain lie. They do not, however, cover the whole surface of these north-western tracts. Un the contrary, they form a broken fringe from Cape Wrath to the Island of Raasay, coming out boldly to the Atlantic in the northern half of its course, but throughout the southern portion retiring chiefly towards the heads of the bays and sea-lochs, and even extending inland to the head of I.och Maree. The reason of this want of continuity is to be found in the spread of later formations over the gneiss. At the base of these overlying deposits comes a mass of dark red sandstone and conglomerate (classed as Cambrian by Murchison and his associates), which, in gently inclined or horizontal strata, sweeps across the platform of gnciss, rising here and there into solitary cones or groups of cones fully 3,400 feet above the sea. No contrast in Highland scencry is more abrupt and impressive than that between the ground occupied by the old gneiss and that covered by this overlying sandstone group. So sharp is the line of demarcation between the two tracts that it can be accurately followed by the eye even at a distance of several miles. Where the sandstone supervenes, the tumbled sea of bare grey gneiss is succeeded by smooth heathy slopes, through which the flat or gently-inclined parallel edges of the beds protrude in suecessive lines of terrace. As the ground rises into conical mountains, the covering of beather grows more and more scant, but the same terraced bars of rock continue to rise even to the summits, so that these vast solitary cones, standing apart on their platform of gneiss, have rather the aspect of rudely symmetrical pyramids than the frce, bold sweep of crag and slope so characteristic of other Scottish mountains.

The depth of these sandstones must amount to several thousand feet. IVven in single mountains a thickness of more than three thousand four hundred feet can be taken in at a glance of the eye from luase to summit. Yet when this massive formation is followed along the belt of country in which it lies it is found to thin out rapidly and even for some distance to disappear. Such a disappearance night arise cither because the formation was not continuously deposited or because it was unequally worn down before the next formation was accumulated upon it. Evidently the solution of this question will have an important bearing on any reconstruction of the early geography of the region.

$A$ bove the red sandstones and crecping across them transgressivcly lies the cieep pile of white quartzites, limestones, and schists which Peach's discovery of recognisable fossils in them at Dutness showed to be of Lower Silurian age. Another well-marked contrast of scenery is presented where these rocks abut upon those just described. The quartzites risc into long lines of bare white hills which, as the rock brcaks up under the influence of the weather, are apt to be buried under their own débris even up to the summits. Here and there outlying patches of the white rock may be seen gleaming along the crests of the dark sandstone mountains like fields of snow or nascent glaciers. Quartzites, limestones, and schists dip away to the east and pass under the vast serics of younger schists which form most of the rest of the Scottish Highlands. This order of succession, first established by Murchison, can be demonstrated by innumerable lines of natural section. I have myself traced it through the mountainous country from Cape Wrath to Skye, and in many traverses across Sutherland and Ross. I have sought for evidence of the reappearance of the old or fundamental gneiss of the north-west, and have ransacked cvery Iighland county in the search, but have never found the leitst trace of that rork beyond its limits in Sutherland and Ross. Its distinctive gneisses and other crystalline masses, so wonderfully unlike anything else in the Ilighlands, never reappear to the east. And that strange inammillated, bossy surface is found in the northwest alone.

To realise what the appearance of the old gneiss at the present surface means we must bear in mind that it was first buried under scveral thousand feet of red sandstone, that the area was then further submerged until the vast pile of scdiment was deposited out of which the High- 
lands have been formed, that these sedimentary accumulations-how many thousand feet thick we cannot yet tell-were subsequently over the Highland area crumpled and metamorphosed into crystalline schists, and that finally towards the west the ancient platform of gneiss was once more ridged up and gradually bared of its superincumbent load of rock, until now at length some portions of it have been once more laid open to the air.

There is thus a special historical interest in this fragment of the old gneiss country. It is a portion of the
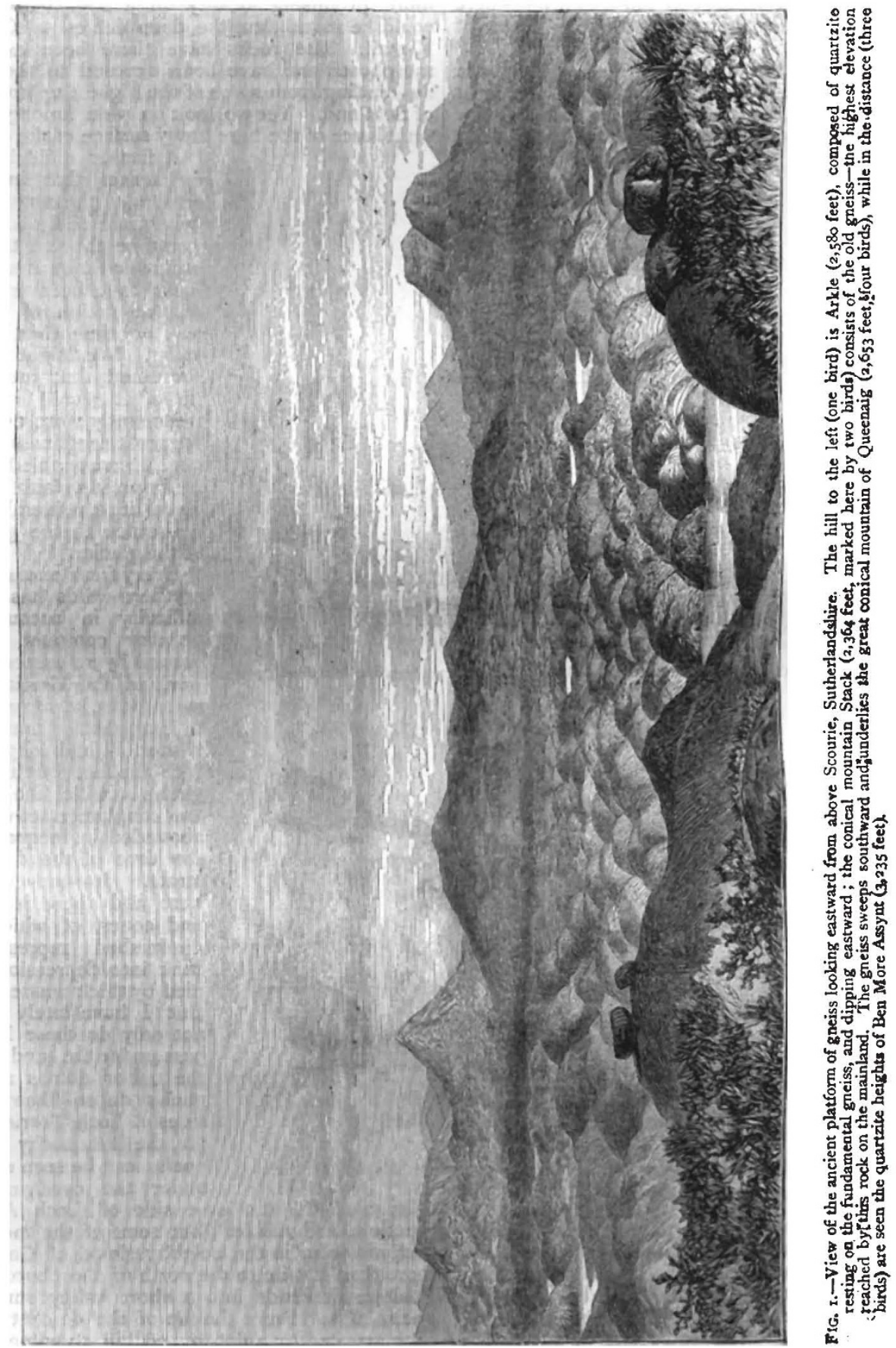
eartiest European surface of which as yet we know any-
thing a surface in chronological comparison with which the Alps are of quite modern date. For many years past I have at intervals wandered over it, finding in its undulations of bare rock 2 fascination which a fairer landscape

might fail to exert. Each visit suggests some fresh problem, if it does not cast light on earlier difficulties. One of twe questions whlch must partioularly engage the attention of every observant traveller in Western Sutherland and Ross is the origin of that extraordinary contour 
presented by the gneiss. A very slight examination shows that every dome and boss of rock is ice-worn. The smoothed polished and striated surface left by the ice of the glacial period is everywhere to be recognised. Each hummock of gneiss is a more or less perfect roche moutonnée. Perched blocks are strewn over the ground by thousands. In short, there can hardly be anywhere else in Britain a more thoroughly typical piece of glaciation.

An obvious answer to the question of the origin of the peculiar configuration of this gneiss country is to refer it to the action of the last ice-sheet which covered Britain. That the gneiss was powerfully ground down by that ice

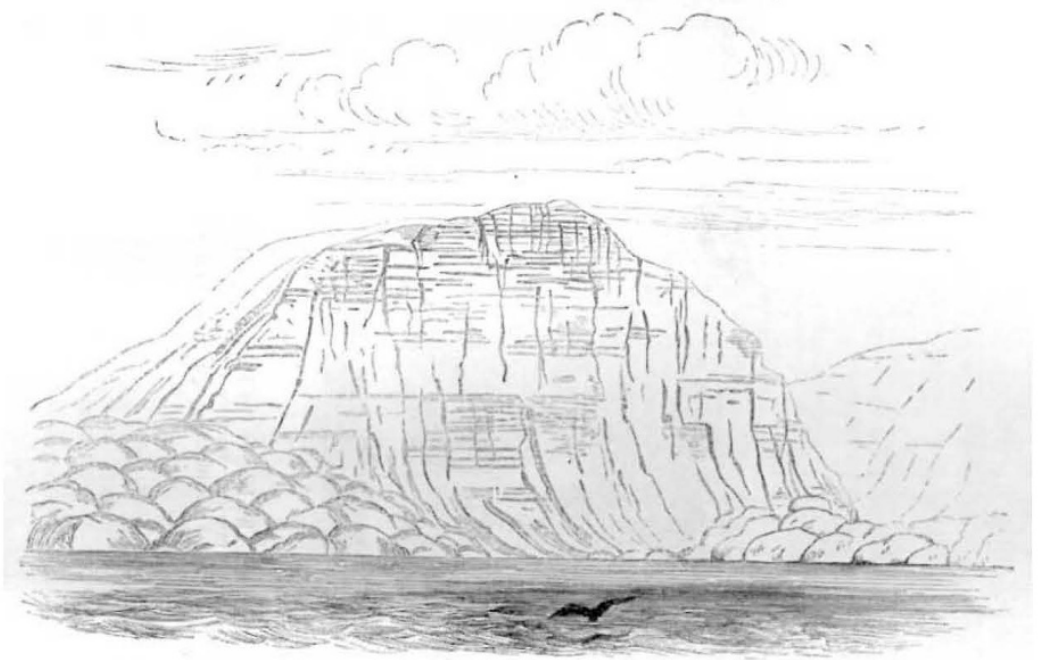

FIG. 2.-Ben Shieldag, Loch Torridon-a hill of fiat Cambrian red sandstone resting upon an uneven hummocky surface of the old gneiss.

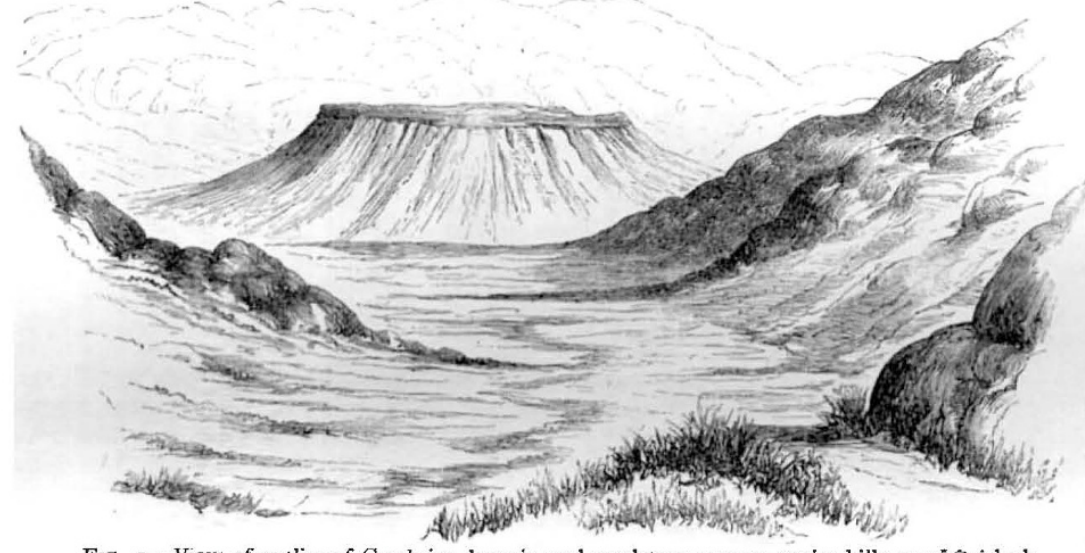

FIG. 3.-View of outlier of Cambrian breccia and sandstone among gneiss hil's near" Gairloch.

is sufficiently manifest. But if the peculiar bossy surface is to be thus explained we are confronted by the difficulty that the ice must have acted far more effectively on the gneiss than on any other rock in the region. Yet there is nothing in the configuration of the ground to make the erosion greater on the gneiss than on the red sandstone or quartzites and schists. The same side of a sea-loch may be seen to present slopes both of gneiss and sandstone; the gneiss is always worn into smooth domes, ridges, and hollows; but the sandstone retains its parallel bands of rocky terrace. The difference is evidently not due to any greater glacial abrasion of the gneiss. The area of high ground above the gneiss platform in Suther- landshire is comparatively small. As shown in Fig. I it rises somewhat steeply from the west, its chief area and drainage lying towards the east. I have visited those tracts of the Highlands where the rocks approach nearest to the type of the ancient gneiss, and where the conditions have been most favourable for intense glaciation. No more promising locality for a comparison of this kind could be found than the deep defiles of Glen Shiel and Kintail. The rocks have there been extremely metamorphosed and have been exposed to the action of ice descending from some of the highest uplands in the West of Scotland. Yet we look in vain among them for any semblance of the bare bossy surface of the old gneiss.

A further difficulty arises when we reflect that in the general erosion of the country the gneiss, being covered by later formations, would be the last to be attacked, and in so far as it was so covered, must have been exposed to the erosive action of the ice for a shorter time than the overlying rocks. We might therefore have presumed that instead of being more, it would have been less trenchantly worn down than these. Its great toughness and durability, which have enabled it to retain the ice-impress so faithfully, must have given it considerable powers of resistance to the grinding action of the glacier.

Every fresh excursion into these northern wilds has increased my difficulty in accounting for the peculiar contours of the gneiss ground by reference merely to the work of the Glacial period. A recent visit, however, seems at last to have thrown some light on the matter. I had long been familiar with the fact that the platform of gneiss on which the red sandstones and conglomerates were laid down abounded in inequalities even at the time of the deposit of these strata. Its uneven surface rose here and there into high ridges and cones, of which Stack is a diminished representative, and sank into depressions now occupied by thick masses of sandstone. But I have lately observed that not only do these larger features pass under the sandstone, but that the minor domes and bosses of gneiss do so likewise. On both sides of Loch Torridon, for example, the hummocky outlines of the gneiss can be seen emerging from under the overlying sandstones (Fig. 2). On the west side of Loch Assynt similar junctions are visible. But some of the most impressive sections occur in the neighbourhood of Gairloch. Little more than a mile to the north of the church the road to Poolewe descends into a short valley surrounded with gneiss hills. From the top of the descent the eye is at once arrested by a flat-topped hill standing in the middle of the valley at its upper end, and suggesting some kind of fortification; so different from the surrounding hummocky declivities of gneiss is its level grassy top, flanked by wall-like cliffs rising upon a glacis-slope of débris and herbage (Fig, 3). Closer examination shows that the little eminence is capped with a coarse reddish breccia made 
up of fragments from the surrounding gneiss. The stones in this deposit are for the most part perfectly angular, and are sometimes stuck on end in the mass. They underwent but little re-arrangement after they were thrown down, though occasional lenticular seams of red sandstone running through the rock serve to prove that it is lying as a flat cake on the gneiss. My friend $\mathrm{Mr}$. Norman Lockyer accompanied me in the examination of this hill. We searched long for a striated stone among the component materials of the breccia, but the matrix was too firm to allow us to bare and extract any of the pebbles or boulders. We traced, however, the characteristic rounded bossy surface of the gneiss until it passed under the breccia, and were convinced that, could the outlier of breccia be stripped off, the same kind of surface would be found below it as on the gneiss above and around. The valley in which this little fragment of a once more extensive deposit of breccia lies certainly existed as a hollow in
Cambrian times. From the narrowness of its present outlet, which has been cut by the escaping streamlet, and from the nature of the breccia, we may infer with some plausibility that the hollow was filled with water, and may have been a lake. It was almost certainly a rock-basin, surrounded with hills of gneiss that had been worn into undulating dome-shaped hummocks.

Behind the new hotel at Gairloch the ground rises steeply into a rocky declivity of the old gneiss. Along the base of these slopes the gneiss (which is here a greenish schist) is wrapped round with a breccia of remarkable coarseness and toughness. We noticed some blocks in it fully five feet long. It is entirely made up of angular fragments of the schist underneath, to which it adheres with great tenacity. Here again rounded and smoothed domes of the older rock can be traced passing under the breccia, as at $a$ in Fig. 4. On the coast immediately to the south of the new Free Church a series of
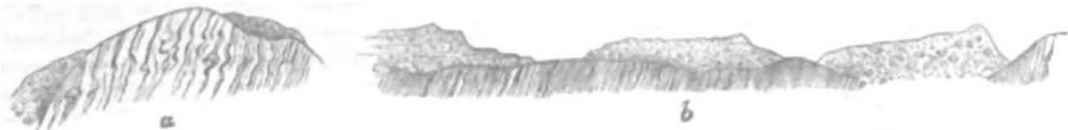

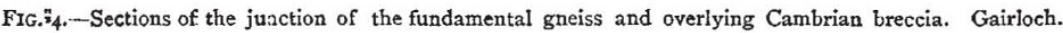

instructive sections again lays bare the worn undulating platform of gneiss, with its overlying cover of coarse angular breccia (b in Fig. 4).

On these far northern shores, then, there still remain fragments of the surface on which our oldest sedimentary accumulations were deposited. These fragments are found to bear in their smoothed hummocky contours a striking resemblance to the surface which geologists now always associate with the action of glacier-ice. There can at least be no doubt that they are denuded surfaces. The edges of the vertical and twisted beds of gneiss and schist have been smoothly bevelled off. These rocks, however, would never have assumed such a contour if exposed merely to ordinary sub-aërial disintegration. They would have taken sharp craggy outlines like those which are here and there gradually replacing the ice-worn curves of the roches moutonnées. They have certainly been ground by an agent that has produced results which, if they were found in a recent formation, would, without hesitation, be ascribed to land-ice. The breccia, too, is quite comparable to moraine-stuff. Without wishing at present to prejudge a question on which I hope yet to obtain further evidence, I think we have in the meantime grounds for concluding that in the northwest of Scotland there is still traceable a fragment of the earliest known land-surface of Europe, that this primeval country had a smooth undulating aspect not unlike that of the west of Sutherland at the present time, that it contained rock-hollows, some of them filled with water, that into these hollows piles of coarse angular detritus were thrust, that around and beneath the tracks where this detritus accumulated the gneiss was worn into domeshaped forms strongly suggestive of the operation of land-ice, and that though the ice of the last Glacial Period undoubtedly ground down the platform of gneiss, bared as it was of the overlying formations, it found a surface already worn into approximately the same forms as those which it presents to-day. ARCH. GEIKIE

\section{EXCRETION OF WATER BY LEAVES ${ }^{1}$}

IN the pamphlet referred to below Dr. Moll gives a detailed account of his investigations upon the excretion of drops of water by leaves, of which an outline was given in the Botanische Zeitung for January 23 of the present year.

The question with which he more especially deals is as to whether this excretion is a function which is performed by all leaves, or whether it is confined to such leaves only as possess specially modified organs. The method which he employed in his researches is to place the leaves under the most favourable condition for the excretion of drops by diminishing as far as possible their transpiration, and by supplying them with water. Under ordinary circumstances the excretion of drops is due to the action of the root-pressure; but Dr. Moll substitutes for this, in his experiments, the pressure of a column of mercury, in order to have this important factor in the problem completely under control.

The results, which are of considerable interest, may be briefly stated as follows : out of sixty plants experimented on, the leaves of twenty-nine excreted drops without becoming injected, that is, without their intercellular spaces becoming filled with water; thirteen leaves became injected and excreted drops, and eighteen became injected but did not excrete at all. It appears that the age of the leaf has a very evident influence upon the excretion of drops, for whereas the young leaves of a plant, such as Sambucus nigra or Platanus occidentalis, for instance, readily excrete drops without becoming injected, the older leaves of the

x " Untersuchungen über Tropfenausscheidung und Injection bei Blättern," ron Dr. J. W. Moll. (Amsterdam, 1880.) same plant become injected and excrete scarcely at all. Under these circumstances it is quite possible and even probable, as Dr. Moll himself suggests, that of the eighteen plants the leaves of which became only injected, some at least were capable of excretion at an earlier period. It is only definitely stated of Hedera, Syringa, and Taxus that their leaves do not excrete at all.

As to the organs of excretion, it is effected in eight out of the forty-two cases by means of water-pores, but in four of these cases it is effected also by ordinary stomata; in eight other cases it was found to be effected by stomata, and in three cases it took place at portions of the surface which possessed neither waterpores nor stomata. These last cases are carefully distinguished by Dr. Moll from those in which an excretion took place over the whole surface of the leaf in consequence of exces ive pressure.

From these observations it appears that most leaves, at least so long as they are comparatively young, are capable of excreting water in drops when it is supplied to them in excess, and further, that this excretion is effected by certain organs (Emissarien the author calls them) which may be water-pores, or ordinary stomata, or limited areas of the surface which are histologically undifferentiated. The effect of this excretion is to prevent the injection of the leaves when the root-pressure is great, a condition which would obviously interfere with the circulation of air in the intercellular spaces, and therefore with the function of the leaf. Dr. Moll suggests that possibly some definite correlation exists between the presence of excretory organs and the existence of root-pressure in a plant; for instance, according to Hofmeister ("Flora," 1862), no root-pressure can be detected in Conifers, 